\title{
Correction to: Applications and potential of genome editing in crop improvement
}

\author{
Yi Zhang ${ }^{1}$, Karen Massel2 ${ }^{2}$ lan D. Godwin ${ }^{2}$ and Caixia Gao ${ }^{3,4^{*}}$
}

\section{Correction to: Genome Biology \\ https://doi.org/10.1186/s13059-018-1586-y}

Following publication of the original article [1], the authors reported the following two errors:

1. Page 5, paragraph 3, line 4: "Polyphenol oxidase (PPO) is an enzyme that causes browning in many fruits and vegetables. By knocking out this gene, Waltz and coworkers developed a non-browning mushroom". "Waltz and coworkers" should be "Yinong Yang and coworkers".

2. Page 6, paragraph 2, line 3: "Adenine-deaminasemediated base editing (ABE) is more complicated than $\mathrm{CBE}$ because no known naturally occurring cytidine deaminases catalyze adenine deamination in DNA rather than RNA". "naturally occurring cytidine deaminases" should be "naturally occurring adenine deaminases".

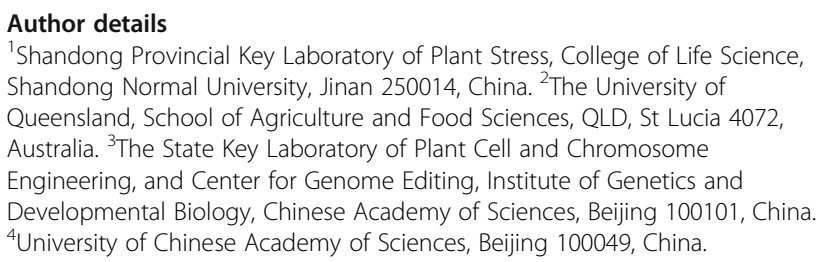

Received: 2 January 2019 Accepted: 4 January 2019

Published online: 16 January 2019

\section{Reference}

1. Zhang, et al. Applications and potential of genome editing in crop improvement. Genome Biol. 2018;19:210. https://doi.org/10.1186/s13059018-1586-y.

\footnotetext{
* Correspondence: cxgao@genetics.ac.cn

${ }^{3}$ The State Key Laboratory of Plant Cell and Chromosome Engineering, and Center for Genome Editing, Institute of Genetics and Developmental Biology, Chinese Academy of Sciences, Beijing 100101, China

${ }^{4}$ University of Chinese Academy of Sciences, Beijing 100049, China

Full list of author information is available at the end of the article
}

(c) The Author(s). 2019 Open Access This article is distributed under the terms of the Creative Commons Attribution 4.0 International License (http://creativecommons.org/licenses/by/4.0/), which permits unrestricted use, distribution, and reproduction in any medium, provided you give appropriate credit to the original author(s) and the source, provide a link to the Creative Commons license, and indicate if changes were made. The Creative Commons Public Domain Dedication waiver (http://creativecommons.org/publicdomain/zero/1.0/) applies to the data made available in this article, unless otherwise stated. 